\title{
Giant Ludwig Angina Reason of Airway Obstruction
}

\author{
Yüce İslamoğlu' (10), Tural Fetullayev², Süha Beton², Başak Ceyda Meco³, Cem Meco² \\ 1'Department of Otorhinolaryngology and Head Neck Surgery, Ankara Atatürk Training and Research Hospital, Ankara, Turkey \\ 2Department of Otorhinolaryngology and Head Neck Surgery, Ankara University School of Medicine, Ankara, Turkey \\ ${ }^{3}$ Department of Anesthesia and Reanimation, Ankara University School of Medicine, Ankara, Turkey
}

Cite this article as: İslamoğlu Y, Fetullayev T, Beton S, Meco BC, Meco C. Giant Ludwig Angina Reason of Airway Obstruction. JAREM 2018; 8(2): 116-8.

\begin{abstract}
Ludwig angina is an aggressively spreading phlegmon or cellulite affecting the mouth floor and submandibular and sublingual tissues of the mouth. The disease is mostly seen in patients aged 20-50 years with abscess or gingivitis of lower teeth. Early diagnosis is very important because this is a life-threatening disease. A 55-year-old male patient with the complaints of high body temperature despite the usage of intravenous antibiotics, somnolence, increased difficulty in breathing, and swelling in the neck was diagnosed with Ludwig angina and abscess was urgently drained. Head-neck region abscess intervened by team work can cause less mortality and morbidity.

Keywords: Ludwig angina, airway obstruction, neck abscess
\end{abstract}

ORCID IDs of the author: Y.i. 0000-0002-1294-7088.

\section{INTRODUCTION}

Ludwig angina is an aggressively spreading phlegmon or cellulite affecting the mouth floor and submandibular and sublingual tissues of the mouth. It was defined for the first time by Wilhelm Friedrich von Ludwig in 1836 as "gangrenous inflammation of the connective tissue of the neck progressing to tissues around the small muscles between larynx and mouth floor" (1). The disease is mostly seen in patients aged 20-50 years with abscess or gingivitis of lower teeth (2). Incidence of Ludwig angina in men is reported to be 2-3 times more than that in women. Early diagnosis is very important because this is a life-threatening disease and is more frequently seen after long-term neglected dental hygiene. Increased dental care and easy communication with dentist decreased the incidence of the disease, caused by this reason (3). In this report, the patient was diagnosed approximately after 15 days. Written patient consent was obtained from the patient for this publication.

\section{CASE PRESENTATION}

A 55-year-old male patient was directed to tertiary Ankara University School of Medicine Ibni Sina Hospital with the complaints of non-decreasing high body temperature despite the usage of intravenous antibiotics, somnolence, increased difficulty in breathing, and swelling in the neck. Clinical history revealed that sore throat, swelling in the neck, difficultly in swallowing, and trismus complaints started approximately 20 days before and increased by the time of the visit, and for 2 weeks oral intake was low. Blood analysis revealed $\mathrm{Na}=120$ $\mathrm{mEq} / \mathrm{L}$ and $\mathrm{Cl}=77 \mathrm{mEq} / \mathrm{L}$; the body temperature of the patient was $38.5^{\circ} \mathrm{C}$. The patient, who had reduced mouth opening and tongue motion, had bad dental hygiene and gingivitis. Flexible endoscopic inspection revealed fluctuant mass in the submental area with unknown boundaries and clearly narrowed airway between tongue base and oropharynx (Figure 1). Patient was followed up for hypertension and type 2 diabetes mellitus diagnoses. He was diagnosed with bipolar affective abnormality 15 years, had not been taking medications for it for the last 5 years. Computer tomography of the neck revealed a $7.5 \times 5.5$ $\mathrm{cm}$ lesion compatible with abscess, which caused pressure on the oropharynx under the tongue (Figure 2). It was decided urgently to drain the abscess narrowing the airway and causing somnolence. However, because the mouth opening was limited and area was reduced due to the abscess pressure, opening of tracheotomy with local anesthesia for the control of the airway and subsequently draining the abscess under general anesthesia was last decision. However, patient did not conform to the tracheotomy; therefore, it was decided to try intubation in awake condition. After urgent tracheotomy preparations, the patient was intubated by anesthesia team with the help of flexible endoscopy in awake condition. Abscess (approximately 150 cc pus) was drained (Figure 3). Nasogastric probe was placed for feeding and decided not to extubate for edema in airway to pass. Two days after the operation, the patient was smoothly extubated, oral feeding was started, and general state and blood values had improved. Six days after the operation, the patient was discharged from the hospital. Consent form was taken from the patient for this paper.

\section{DISCUSSION}

The main principle in the treatment of Ludwig angina is early diagnosis (4). If early diagnosis is done, the disease can be treated 


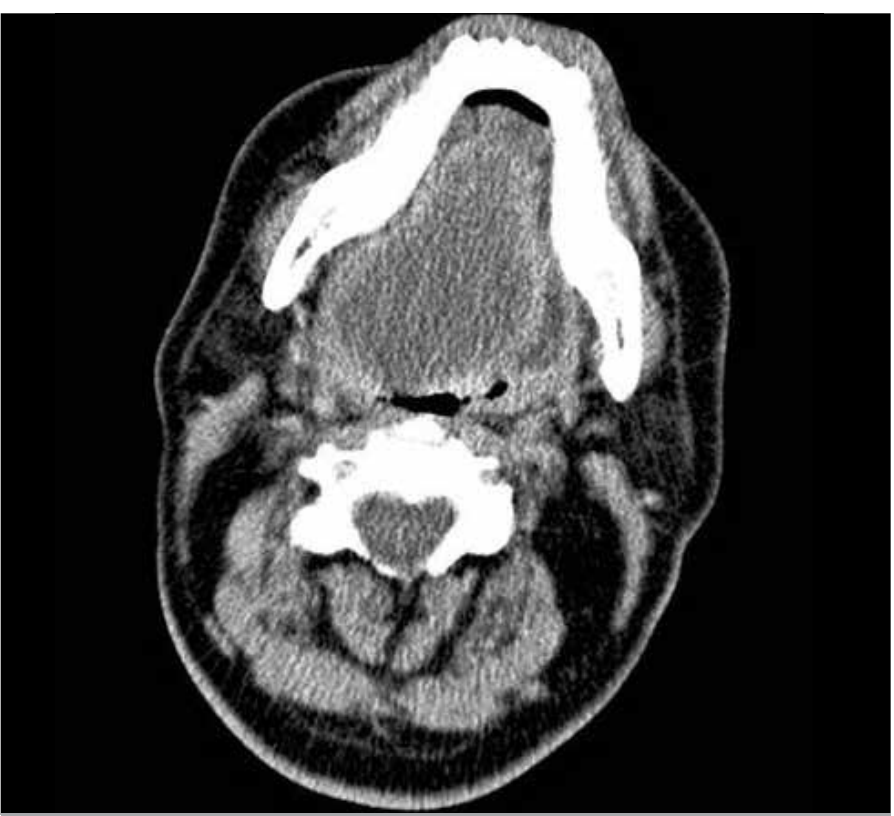

Figure 1. Computer tomography scan of the abscess

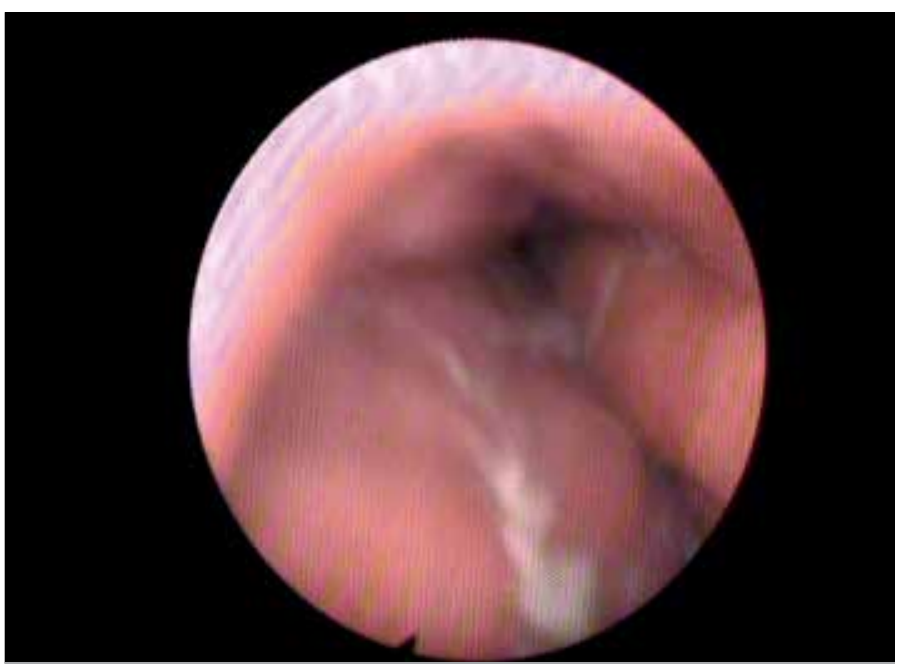

Figure 2. Endoscopic view of the abscess

before complications occur and danger for life is decreased. In our case, because of late diagnosis, malnutrition and delirium occurred. In addition, the size of the abscess increased and endangered the airway.

Despite the usage of very effective antibiotics, the mortality ratio is $8 \%-9 \%$ because of the large number of complications involved with Ludwig angina. Usual complications include mediastinitis, asfixia, septicemia, and empyema (5). Asfixia and aspiration is related to insufficient protection of airway, so urgently discharging abscess, intubation, or tracheotomy should be performed for airway safety. However, during the operation may be intubation could not be done because of the abscess rupture and patient could be lost (6). Therefore, intubation should be performed by experienced persons; if enough equipment exists, even nasotracheal should be tried. At that moment, conditions should be prepared for urgent tracheotomy. Therefore, in this clinical picture, if the operation is done under emergen-

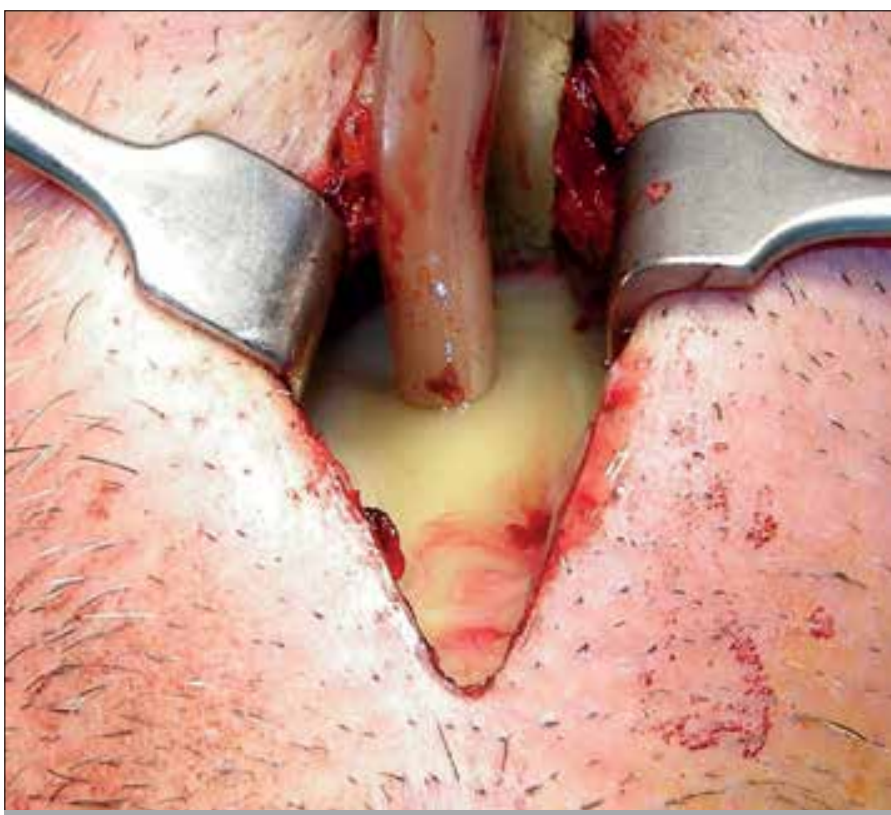

Figure 3. Drained abscess

cy room conditions, an anesthesiologist and otolaryngologist should be urgently called for emergency service. In our case, intubation was performed under operating room conditions with the flexible endoscope. This case should be role to clinicians because in a case of giant Ludwig angina, the patient could be intubated and tracheostomy abandoned.

Abscess drainage can be tried with injection aspiration, but in cases of dense or excessive abscess content, insicion drainage followed by drainage application is needed. Antibiotic treatment should be initiated immediately after abscess is drained. Considering flora elements of mouth cavity, particularly that $75 \%$ of the flora are anaerobic bacteria, anaerob effective antibiotics must be included in the treatment regime (5). In our case, treatment with intravenous sulbactam ampicillin and metronidazole was started.

\section{CONCLUSION}

Airways can be in danger very frequently because of the complex abscess in the head-neck area. Although these abscesses are frequently seen, they can be confused with other diseases, thereby delaying the diagnosis. Emergency doctors should be careful with airway problems and be prepared for possible complex cases.

Informed Consent: Written informed consent was obtained from patient who participated in this case.

Peer-review: Externally peer-reviewed.

Author Contributions: Concept - Y.I., T.F., S.B., B.C.M., C.M.; Design - Y.I., T.F., S.B., B.C.M., C.M.; Supervision - Y.I., T.F., S.B., B.C.M., C.M.; Resources - Y.I., T.F., S.B., B.C.M., C.M.; Materials - Y.i., T.F., S.B., B.C.M., C.M.; Data Collection and/or Processing - Y.I., T.F., S.B., B.C.M., C.M.; Analysis and/or Interpretation - Y.I., T.F., S.B., B.C.M., C.M.; Literature Search - Y.I.; Writing Manuscript - Y.I., T.F., S.B., B.C.M., C.M.; Critical Review - Y.I., T.F., S.B., B.C.M., C.M.; Other - Y.I., T.F., S.B., B.C.M., C.M.

Conflict of Interest: The authors have no conflicts of interest to declare. 
Financial Disclosure: The authors declared that this study has received no financial support.

\section{REFERENCES}

1. Von Ludwig WF, "Über eine in neuerer Zeit wiederholt hier vorgekommene Form von Halsentzündung. Medicinisches Correspondenzblatt des Württembergischen ärztlichen Vereins," Stuttgart, vol. 6, pp. 21-25, 1836.

2. Quinn Jr FB, "Ludwig angina," Archives of Otolaryngology—Head \& Neck Surgery, vol. 125, p.599, 1999. [CrossRef]
3. DeAngelis AF, Barrowman RA, Harrod R, Nastri AL. Review article: Maxillofacial emergencies: oral pain and odontogenic infections. Emerg Med Australas 2014; 26: 336-42. [CrossRef]

4. Kassam K, Messiha A, Heliotis M. Ludwig's Angina: The Original Angina. Case Rep Surg 2013; 2013: 974269. [CrossRef]

5. Sethi DS, Stanley RE. Deep neck abscess: changing trends. J Laryngol Otol 1994; 108: 138-43. [CrossRef]

6. Fellini RT, Volquind D, Schnor OH, Angeletti MG, Souza OE. Airway management in Ludwig's angina - a challenge: case report. Rev Bras Anestesiol 2017; 67: 637-40. [CrossRef] 